ARTIGO TÉCNICO

\title{
Estratégias de mercado para produtores
}

\author{
AUGUSTO AKI ${ }^{(1)}$
}

\section{CENÁRIO}

O que se percebe em um mercado onde a oferta cresce e a demanda não responde é que um processo de seleção natural entra em cena. O produtor começa por ter perdas financeiras (inadimplência), que se transformam em negligência na qualidade dos produtos e nos processos de manuseio do produto. Daí, seguem-se a descrença no associativismo e o canibalismo.

Nesse momento o custo comercial torna-se insuportável, pois tentamos abrir espaço em qualquer direção e já não existe mais uma estratégia, apenas uma guerrilha de subsistência.

Nessa cadeia, quem tem o maior patrimônio é o produtor (infelizmente, quase sempre concentrado na produção e pouco representativo na comercialização) e, com a desestruturação da cadeia, esse patrimônio se desvaloriza, aumentando as perdas.

No final, alguns saem para outros produtos e o mercado torna-se informal.

Mesmo quando em conjunto, mas sem uma estratégia definida, o produtor também padece dos mesmos problemas. Temos visto centrais de comercialização fechando e ou passando por maus bocados. Uma ação sobre o associativismo, disciplina individual e determinação precisam ser a base para mudar esse destino. O mercado de flores não está em extinção, mas irão sair dele aqueles que não conseguirem parar para pensar e mudar a sequência dessa tragédia grega...

\section{CAMINHOS}

Os caminhos que sugiro abaixo não são idéias iluminadas de uma noite de verão nem frutos de genialidade, mas a comparação com casos semelhantes em outros mercados. Vamos a elas.

\section{Ferramenta comercial eficiente}

O que sustenta o Veiling é sua ferramenta de comercialização, eficiente e de baixo custo, e seu sistema de logística e distribuição. Assim, mesmo com um mercado fraco, o efeito é menor para os produtores do Veiling. Isso permite que tenham resultados sobre os concorrentes, enquanto o mercado não cresce. Ela foi construída com determinação e dor. Para isso foi usada uma forte base associativista. Cada produtor tem que ser capaz de fazer sua parte e de suportar os prejuízos para manter o grupo existindo (se a confiança existe e se a ferramenta comercial é boa). O Veiling não é o único modelo. Tenho visto produtores que foram em conjunto ao varejo (Ponto Flores em SP) ou que foram em conjunto para o Atacado (Flora Agreste em PE) e que também ganharam em competitividade (ainda que também estejam sujeitos às agruras do mercado). O certo é que esses grupos são pequenos, com boa homogeneidade e lideranças envolvidas. Também erraram antes, até chegar ao modelo atual, mas não desistiram. Esse parece ser o modelo que promete um futuro melhor.

\section{Olhar o varejo como prestador de serviço e não como cliente}

Está cada vez mais claro que o cliente do produtor é o consumidor final. Isso não significa dizer que a venda direta é o caminho lógico, mas muda a relação com o varejo. As lojas e os profissionais se transformarão de "Ponto de Venda" em "Ponto de Revenda". Imagine passar a pagar ao varejo uma comissão pela venda dos produtos ao invés de vendê-los. Isso garante uma melhor cobrança sobre o tratamento do produto na loja e as formas de sua exposição e venda. Também permite selecionar mais os clientes (que estarão mais interessados em ter essa parceria). O foco será único no consumidor final e o fantasma da inadimplência será eliminado. Ademais, o produtor terá maior poder sobre sua demanda final, mas para isso será preciso organização em grupos para dar suporte às vendas nas lojas.

\section{Inovar, iniciativa e deixar experimentar}

Para aumentar a competitividade das flores no consumidor final, precisamos de muito mais atividade. Eles compram por conveniência, em locais onde foram buscar outros produtos/serviços e quando o preço está conveniente. Isso seria bom se o volume compensasse. Precisamos provocar mais esse consumo de conveniência, criando motivos para compra. A relação do varejo com o consumidor precisa ser mais profissional e frequente. Precisamos nos unir em micro cadeias para viabilizar isso. Informação é venda.

${ }^{(1)}$ Consultor. e-mail: augustoaki@dglnet.com.br.www.negocioscomflores.com.br 
Desinformação é queda de preço e descapitalização (compra de oportunidade não sustenta um mercado).

\section{Selecionar melhor o que produzir}

Estive visitando algumas regiões produtoras onde a atuação familiar e informal é mais forte. Em geral, focamse na produção de pequenos arbustos para paisagismo, com grande variedade e baixa qualidade (classificação, padronização e controle fitossanitário). Todos têm muita coisa e todos têm a mesma coisa. Ficam na beira das estradas e vendem ao menor preço. Tá certo que o estoque tem longa longevidade, mas o fluxo de caixa é péssimo e assim, não há fonte de investimento. Sem investimento, um negócio não prosperará. Pior, a guerra de preços impede a ação coletiva. Todos permanecem subsistindo e sem perspectivas. O produtor deve ser criterioso na escolha de seus produtos. Além de zelar pela qualidade do que faz, deve escolher uma maneira de ser único (nos produtos, nos formatos, nos preços/volumes, nas embalagens ou na logística). Sem essa característica única, não se cria valor. Que produtos devemos deixar de produzir? O que produzir de maneira diferente? Onde fazer parcerias? Que novo serviço oferecer? Para o mercado vale a máxima: "quanto mais fácil produzir, pior!".

\section{Oportunidades de produtos}

A verdade e a fé estão com Deus, assim cada um faça sua leitura de mercado. Seguem anexadas algumas possíveis oportunidades:

- Produtos trançados (sanseveria, fícus, sheflera)

- Engorda regional de produtos de paisagismo

- Buquês para supermercados

- Vasos floridos com plantas novas para paisagismo

- Assinatura de flores para empresas

- Viabilizar negócios de baixo custo fixo no varejo

- Atender a clientes distantes (linhas para grotões)

- Criar treinamento para jardineiros

- Olhem para o Projeto Sabores (SEBRAE) e façam um benchmarketing para floriculturas 